\title{
Nematicidal properties of some algal aqueous extracts against root-knot nematode, Meloidogyne incognita in vitro
}

\author{
Ahmed H. Nour El-Deen ${ }^{(* * * *)}$ and Ahmed A. Issa $(* * * * *)$ \\ * Nematology Research Unit, Agricultural Zoology Dept., Faculty of Agriculture, Mansoura University, Egypt. \\ ** Department of Botany, Faculty of Science, Assiut University, Assiut, Egypt. \\ $* * *$ Biology Dept., Faculty of Science, Taif University, Saudi Arabia. \\ Corresponding author: ahnoureldeen2003@yahoo.com
}

\section{Abstract}

The effectiveness of aqueous extracts derived from nine algal species at different concentrations on egg hatching and mortality of Meloidogyne incognita (Kofoid and White) Chitwood juveniles after various exposure times were determined in vitro. Results indicated that Enteromorpha flexuosa at the concentration of $80 \%$ was the best treatment for suppressing the egg hatching with value of $2 \%$ after 5 days of exposure, followed by Dilsea carnosa extract (3\%) and Codium fragile $(4 \%)$ at the same concentration and exposure time. Likewise, application of $C$. fragile, D. carnosa , E. flexuosa and Cystoseira myrica extracts at the concentrations of 80 and $60 \%$ were highly toxic to the nematodes, killing more than $90 \%$ of nematode larva after 72 hours of exposure while the others gave quite low mortalities. The characteristic appearances in shape of the nematodes killed by C. fragile, D. carnosa, C. myrica, E. flexuosa and Sargassum muticum was sigmoid ( $\sum$-shape) with some curved shape; whereas, the nematodes killed by other algal species mostly followed straight or bent shapes. The present study proved that four species of algae C. fragile, D. carnosa, C. myrica and E. flexuosa could be used for the bio-control of root-knot nematodes.

Keywords: Algae, In vitro, Meloidogyne incognita, Nematicidal activity

\section{Introduction}

Plant parasitic nematodes caused significant damage and losses to most agricultural crops in the tropical and sub-tropics (Luc et al., 2005). The root-knot nematodes, Meloidogyne Göldi (Rhabditida: Meloidogynidae) are the most economically important plant parasitic nematodes group that cause serious damage to most agricultural crops worldwide (Sasser et al., 1983). Meloidogyne incognita is the most common species of root-knot nematodes and infects almost all cultivated plants, which makes it perhaps the most damaging of pathogens (Sasser and Freckman, 1987).

For several decades, the use of chemical nematicides is one of the primary means of control for root-knot nematodes. Nowadays, chemical nematicides are 
loosing their popularity among farmers for protecting their crops from nematode infestations because of their harmful effects and environmental pollution that led to an urgent need for safe and more effective options (Zuckerman and Esnard, 1994). Biological control promises to be such an option. The recently one of the biological control practices attempted is the study of suppression effects of cyanobacteria (blue-green algae) on plant-parasitic nematodes. Cyanobacteria are little explored even today, so it may possess the novel metabolites which may not screen yet. Microalgal metabolites have attracted attention, because they are a resource for toxins, and potential new drugs (Shimizu, 2003). A large number of microalgal extracts and/or extracellular products exhibit antimicrobial activity. Methanolic extract of Nostoc was antifungal, herbicidal, nematicidal, and insecticidal (Kumar, 2014). Culture filtrates of the Microcoleus vaginatus (Vaucher) inhibited hatching of $M$. incognita eggs and killed second stage juveniles (Khan et al., 1997).

The use of marine algae as control agent against plant-parasitic nematodes has been studied by many workers (Paracer et al., 1987). Different seaweeds exhibited very significant nematicidal activities (Zaki et al., 2005). Wu et al. (1997) reported the role of betaines in alkaline extracts of the marine brown algae Ascophyllum nodosum (Linnaeus) Le Jolis in suppression of the fecundity of tomato-knot nematodes Meloidogyne javanica and M. incognita. In Pakistan, Rizvi and Shameel (2006) collected twenty two species of seaweeds and tested the nematicidal activity of their methanolic extracts against the larvae of $M$. javanica. They recorded that Stoechospermum polypodioides appeared to be the most active seaweed as it caused $80 \%$ mortality of the nematode larvae after $72 \mathrm{~h}$ exposure to its extract. Ibrahim et al. (2007) stated that treating sunflower plants with marine algae, Botryocladia cabillaceae caused reduction in root galls and egg masses of $M$. incognita as well as increased growth parameters. Certain marine algae from different localities have been reported to exhibit mosquito larvicidal, nematicidal, cytotoxic, antifouling activities (Manilal et al., 2011). Nour El-Deen et al. (2013) reported that application of seaweed extract of the brown algae, A. nodosum with cabbage leaves plus arabic gum gave the best results in terms of reducing galls and egg-masses of $M$. incognita as well as increased basil plant fresh weight to the highest percentage (85.8\%). Khan et al. (2015) evaluated in vitro the nematicidal activity of 32 seaweeds on $M$. javanica egg hatching and larval mortality and recorded that Sargasssum tenerrimum, Padina tetrastromatica and Melanothamnus afaqhusainii gave maximum egg hatching (96\%) and larval mortality (99\%) and $(100 \%)$, in water and methanol extract at $10 \%$ concentration after $72 \mathrm{~h}$ exposure time respectively. Moreover, the use of seaweeds is positive sign against harmful microorganisms which are responsible for considerable losses in agriculture yield. Studies on the nematicidal activity of algae still unexplored except for a few reports. Therefore, the aim of this research paper was to evaluate the nematicidal potential of nine algal species on Meloidogyne incognita egg hatching and $\left(\mathrm{J}_{2} \mathrm{~s}\right)$ mortality in vitro. 


\section{Materials and Methods}

In vitro study was carried out in order to determine the effectiveness of aqueous extracts derived from nine algal species isolated from Jeddah and Taif governorates, Saudi Arabia on egg hatching and mortality of $M$. incognita juveniles.

\section{Nematode source and inocula:}

The root-knot nematode $M$. incognita eggs were extracted from infected coleus (Coleus blumei) roots using $0.5 \% \mathrm{NaOCl}$ solution and shaking for 2 minutes (Hussey and Barker, 1973), while second-stage juveniles $\left(\mathrm{J}_{2}\right)$ were extracted from infected roots by hatching. These eggs and $\mathrm{J}_{2} \mathrm{~S}$ were obtained from a pure culture established from single egg masses of $M$. incognita that previously identified according to the characteristics of its perineal pattern (Taylor and Sasser, 1978) and reared on tomato plants grown in a greenhouse of Biology Department, Faculty of Science, Taif University, KSA.

\section{Algal extracts preparation:}

Nine species of algae were isolated from red sea (Jeddah) and soil in Taif (KSA) was tested for their nematicidal activity. From which, seven marine algae were Enteromorpha flexuosa (Wulfen) J. Agardh, Ulva lactuca (Linnaeus) and Codium fragile (Suringar) Hariot for green algae, Cystoseira myrica (S.G. Gmelin) C. Agardh and Sargassum muticum (Yendo) Fensholt for brown algae and Dilsea carnosa (Schimidel) O. Kuntze and Laurencia nidifica J. Agardh for red algae, two species were isolated from soil namely, Scenedesmus obliquus (Turpin) Kützing (green) and Cyanosarcina fontana Kovácik (blue-green algae). Macroalgae were classified into functional groups according to Rubal et al., (2011) and taxonomic classification followed Algaebase (Guiry and Guiry, 2013). Each species of marine ones was field collected and transported to the laboratory where it was freeze-dried. Aqueous extracts of seven algal species were handpicked and washed thoroughly with seawater to remove debris, sand particles and epiphytes. It was kept in an icebox containing slush ice, transported to the laboratory and washed thoroughly with tap water to get rid of the salts from the surface of the samples. The water was drained off and the algal material was spread on blotting paper to remove excess water. After completely drying, the different seaweed materials were ground to a fine powder using Electrical blender. Forty grams of powdered seaweeds were extracted successively with $200 \mathrm{ml}$ of dist. water in Shaker for $3 \mathrm{~h}$. The extracts were filtered and stored in a refrigerator for future use. On the other hand, S. obliquus and $C$. fontana were cultivated in synthetic medium for 7 days and harvested by centrifugations, then the algal belts $(1 \mathrm{~g} / 100 \mathrm{ml})$ was extracted in dist. water as mentioned above (Issa et al., 2015). 


\section{Nematicidal activity test:}

\section{Egg hatching}

Twenty seven wells of 24-well tissue culture plates were filled with one milliliter of one hundred of nematode eggs and extracts of different algal species at concentrations of $80,60,40,20,10$ and $5 \%$, each of which was replicated three times. Three wells, which received only distilled water, were used as control. The number of malforming eggs and (died or alive) hatched juveniles were recorded using Hawksely counting slide after 5, 10 and 15 days.

\section{Juveniles mortality}

Approximately thirty freshly hatched second stage juveniles of the root-knot nematode, $M$. incognita in one $\mathrm{ml}$ distilled water was poured into wells of 24-well tissue culture plates over one $\mathrm{ml}$ of the tested concentrations. The plates were then covered with the lid and kept in an incubator at $25^{\circ} \mathrm{C}$. A $2 \mathrm{ml}$ of distilled water containing nematode larvae served as control. Each treatment was replicated three times. Dead nematodes were counted and recorded after 24, 48 and $72 \mathrm{~h}$ using Hawksely counting slide. Mobility was confirmed by touching the nematode with a fine needle. Nematodes that appeared no realistic movement were considered as dead. Percentages of the nematode mortality were then calculated and recorded for each concentration. Mortality percentages were transformed to arcsin (Bliss, 1937) values just before statistical analysis. Characteristic shapes of the dead nematodes were studied under the microscope.

\section{Statistical analysis:}

Statistically, the obtained data were subjected to analysis of variance (ANOVA) as a factorial in complete block design (Gomez and Gomez, 1984) followed by Duncan's multiple range test to compare means (Duncan, 1955).

\section{Results}

The aqueous extracts of nine algal species and concentrations (80,60, 40, 20, 10 and $5 \%$ ) in comparison distilled water on egg hatching after 5, 10 and 15 days exposure time as well as mortality percentage of newly hatched juveniles of $M$. incognita after 24, 48 and $72 \mathrm{~h}$ exposure period are shown in Tables (1) and (2), respectively. In general, egg hatching significantly decreased with increase in algal extract concentrations tested after all days of exposure duration, whereas, larval mortality percentages increased with increase in algal extract concentrations tested after the three of exposure durations tested.

\section{Egg hatching:}

Data in Table (1) revealed that among treatments of the aqueous extracts of algae affect on $M$. incognita egg hatching, E. flexuosa, D. carnosa and C. fragile 
applications significantly gave the lowest values that were amounted to $15.9,20.6$ and $22.7 \%$, respectively. On the other hand, the highest percentage of egg hatching was observed by aqueous extract of $C$. fontana with value averaged $66.2 \%$ as compared with control and all other treatments. Moreover, 55.4 and $45.5 \%$ of eggs were hatched in S. obliquus and C. myrica extracts, respectively. Treatments of $S$. muticum, $U$. lactuca and $L$. nidifica in aqueous extracts gave a considerable egg hatching percentages with values of $40.7,38.3$ and $32.6 \%$, respectively.

Table (1): Effect of aqueous extract derived from nine species of algae on Meloidogyne incognita egg hatching in vitro.

\begin{tabular}{|c|c|c|c|c|c|c|c|c|}
\hline \multirow{3}{*}{ Treatments $^{a}$} & \multirow{3}{*}{$\begin{array}{l}\text { Time } \\
\text { (Days) }\end{array}$} & \multicolumn{6}{|c|}{ Hatchability $\%^{\text {b }}$} & \multirow{3}{*}{$\begin{array}{l}\text { Tr. } \\
\text { Mean }\end{array}$} \\
\hline & & \multicolumn{6}{|c|}{$\begin{array}{c}\text { Concentration } \\
(\%)\end{array}$} & \\
\hline & & 80 & 60 & 40 & 20 & 10 & 5 & \\
\hline \multirow{3}{*}{ Enteromorpha flexuosa } & 5 & $2 x y$ & $7 v$ & $16 s-u$ & $19 \mathrm{st}$ & $21 r$ & $24 q$ & \multirow{3}{*}{$15.9 \mathrm{j}$} \\
\hline & 10 & $3 x$ & $8 \mathrm{vw}$ & $17 s-u$ & $20 r-t$ & 22 rs & $26 p-r$ & \\
\hline & 15 & $3 x$ & 9.7 uv & $18 \mathrm{~s}$ & $21 r$ & 22 rs & $27 p$ & \\
\hline & 5 & $20.7 r$ & $25 \mathrm{qr}$ & $28 p q$ & $35 n-p$ & $38.7 \mathrm{~m}$ & $39 \mathrm{~m}$ & \\
\hline \multirow[t]{3}{*}{ Laurencia nidifica } & 10 & $22.7 \mathrm{q}-\mathrm{s}$ & $26 p-r$ & 300 & 37 no & $40 m-0$ & $41 \mathrm{~m}-\mathrm{o}$ & \multirow[t]{3}{*}{$32.6 \mathrm{~g}$} \\
\hline & 15 & $23.7 q$ & $27 p$ & $31 o-q$ & $38 \mathrm{~m}$ & $42 \mathrm{mn}$ & $42.7 \mathrm{mn}$ & \\
\hline & 5 & 33 op & $35 n-p$ & 37 no & $39.7 \mathrm{~m}-\mathrm{o}$ & $40 \mathrm{~m}-\mathrm{o}$ & $48 \mathrm{k}$ & \\
\hline \multirow[t]{3}{*}{ Sargassum muticum } & 10 & $35 n-p$ & 36.3 no & $38 \mathrm{~m}$ & $40.7 \mathrm{~m}-\mathrm{o}$ & 441 & 49 k-m & \multirow[t]{2}{*}{$40.7 \mathrm{e}$} \\
\hline & 15 & 37 no & 36.3 no & $39 \mathrm{~m}$ & $42 \mathrm{mn}$ & $46.3 \mathrm{~lm}$ & $51 \mathrm{j}$ & \\
\hline & 5 & $50 \mathrm{kl}$ & 47 Im & $44 I$ & $40 \mathrm{~m}-\mathrm{o}$ & $23.3 q$ & $16.7 \mathrm{~s}-\mathrm{u}$ & \\
\hline \multirow[t]{3}{*}{ Ulva lactuca } & 10 & $51 \mathrm{j}$ & $48 \mathrm{k}$ & $45.7 \mathrm{I}-\mathrm{n}$ & $41 \mathrm{~m}-\mathrm{o}$ & $26 p-r$ & $19 \mathrm{st}$ & \multirow[t]{3}{*}{$38.3 \mathrm{f}$} \\
\hline & 15 & $53 \mathrm{i}$ & $50 \mathrm{kl}$ & $46.3 \mathrm{Im}$ & $41 \mathrm{~m}-\mathrm{o}$ & $27 p$ & $20.7 r$ & \\
\hline & 5 & $66 \mathrm{~h}-\mathrm{j}$ & $62 \mathrm{~h}$ & 54 i-k & $53 i$ & $46.7 \mathrm{Im}$ & $43 \mathrm{mn}$ & \\
\hline \multirow[t]{2}{*}{ Scenedesmus obliquus } & 10 & $68 \mathrm{~g}$ & 64 hi & $55 \mathrm{ij}$ & $54 \mathrm{i}-\mathrm{k}$ & $48 \mathrm{k}$ & $45 \mathrm{I}-\mathrm{n}$ & \multirow[t]{2}{*}{$55.4 \mathrm{c}$} \\
\hline & 15 & $69 \mathrm{~g}$ & $64 \mathrm{hi}$ & $55 \mathrm{ij}$ & $55 \mathrm{ij}$ & $50 \mathrm{kl}$ & $45 \mathrm{I}-\mathrm{n}$ & \\
\hline \multirow{2}{*}{ Cyanosarcina fontana } & 5 & $86 \mathrm{e}$ & $73 f$ & $70 \mathrm{gh}$ & $62 \mathrm{~h}$ & $50 \mathrm{kl}$ & $45 \mathrm{I}-\mathrm{n}$ & \multirow[b]{2}{*}{$66.2 \mathrm{~b}$} \\
\hline & 10 & $89 \mathrm{~d}$ & $74.3 \mathrm{fg}$ & $71 \mathrm{gh}$ & 64.7 hi & $52 \mathrm{jk}$ & $48 \mathrm{k}$ & \\
\hline & 15 & $90.7 \mathrm{~cd}$ & $76.3 \mathrm{f}-\mathrm{h}$ & $72 \mathrm{~g}-\mathrm{i}$ & $66 \mathrm{~h}-\mathrm{j}$ & $53 \mathrm{i}$ & 49 k-m & \\
\hline \multirow{3}{*}{ Dilsea carnosa } & 5 & $3 x$ & $7 v$ & $20.7 \mathrm{r}$ & $25 q r$ & $28 p q$ & 30 o & \multirow{3}{*}{$20.6 \mathrm{i}$} \\
\hline & 10 & $4.3 w x$ & $11 \mathrm{u}$ & 22 rs & $27 p$ & 300 & $320-q$ & \\
\hline & 15 & $5 w-y$ & $11 \mathrm{u}$ & $24 \mathrm{q}$ & $28 p q$ & 300 & 33 op & \\
\hline \multirow{3}{*}{ Codium fragile } & 5 & $4 w x$ & $9 u-w$ & $24 \mathrm{q}$ & $28 p q$ & $28 p q$ & 30.7 o-q & \multirow{3}{*}{$22.7 \mathrm{~h}$} \\
\hline & 10 & $5.3 w$ & $10 \mathrm{uv}$ & $27 p$ & $28 p q$ & 300 & $34 \mathrm{n}$ & \\
\hline & 15 & $7 v$ & $12 \mathrm{t}$ & 300 & $31.3 \mathrm{o}-\mathrm{q}$ & 33 op & $38 \mathrm{~m}$ & \\
\hline \multirow{3}{*}{ Cystoseira myrica } & 5 & $5 w-y$ & $12 \mathrm{t}$ & $46.3 \mathrm{Im}$ & $50 \mathrm{kl}$ & $68 \mathrm{~g}$ & 79 e & \multirow{3}{*}{$45.4 \mathrm{~d}$} \\
\hline & 10 & $7.7 \mathrm{vw}$ & $13 t-v$ & $48 \mathrm{k}$ & $52 \mathrm{jk}$ & $72 \mathrm{~g}-\mathrm{i}$ & 81.7 ef & \\
\hline & 15 & $10 \mathrm{uv}$ & $14 \mathrm{tu}$ & $48.3 \mathrm{k}-\mathrm{m}$ & $54 \mathrm{i}-\mathrm{k}$ & $74 \mathrm{fg}$ & 83 e-g & \\
\hline \multirow{3}{*}{$\mathrm{N}$ alone $(\mathrm{Ck})^{\mathrm{c}}$} & 5 & \multirow{3}{*}{\multicolumn{6}{|c|}{$\begin{array}{c}92.7 \mathrm{c} \\
96.3 \mathrm{~b} \\
100 \mathrm{a}\end{array}$}} & \multirow{3}{*}{$96.3 \mathrm{a}$} \\
\hline & 10 & & & & & & & \\
\hline & 15 & & & & & & & \\
\hline \multicolumn{2}{|l|}{ Conc. Mean } & $38.1 \mathrm{e}$ & $38.6 \mathrm{~d}$ & $44.9 \mathrm{c}$ & $46 \mathrm{~b}$ & $46 \mathrm{~b}$ & $47 a$ & \\
\hline & & of three & plicate & & & & & \\
\hline Means in each colum & & d by the & ame lett & did not & & م & rding to & \\
\hline
\end{tabular}

The interaction between the three factors tested showed that E. flexuosa at the concentration of $80 \%$ was the best treatment for suppressing the egg hatching with value of $2 \%$ after 5 days of exposure, followed by $D$. carnosa extract (3\%) and C. fragile $(4 \%)$ at the same concentration and exposure time. The highest percentage of egg hatching $(100 \%)$ was obtained from distilled water (control) 
treatment after 15 days, followed by $C$. fontana extract at $80 \%(90.7 \%)$, then $C$. myrica extract at 5\% (83\%).

\section{Juveniles mortality:}

Data presented in Table (2) showed the efficacy of algal species at six concentrations on $M$. incognita mortality percentages. Likewise, a similar trend was observed concerning larval mortality percentages that were increased as the concentrations and exposure durations increased. Aqueous extract of $C$. fragile gave the highest percentage of $M$. incognita mortality with value of $86.7 \%$, followed by $D$. carnosa (82.9\%), then C. myrica (73.3\%); whereas, S. obliquus gave the least value of larval mortality $(1.7 \%)$. Moderate mortality percentage values of $\mathrm{J}_{2}$ were obtained when exposed to C. fontana, U. lactuca, L. nidifica and S. muticum that averaged $42.4,35.7,31.5$ and $29.3 \%$, respectively.

Table (2): Effect of aqueous extract derived from nine species of algae on Meloidogyne incognita second stage juvenile $\left(\mathrm{J}_{2}\right)$ mortality in vitro.

\begin{tabular}{|c|c|c|c|c|c|c|c|c|}
\hline \multirow{3}{*}{ Treatments $^{a}$} & \multirow{3}{*}{$\begin{array}{c}\text { Time } \\
\text { (Days) }\end{array}$} & \multicolumn{6}{|c|}{ Mortality $\%^{b}$} & \multirow{3}{*}{$\begin{array}{c}\text { Tr. } \\
\text { Mean }\end{array}$} \\
\hline & & \multicolumn{6}{|c|}{$\begin{array}{c}\text { Concentration } \\
(\%)\end{array}$} & \\
\hline & & 80 & 60 & 40 & 20 & 10 & 5 & \\
\hline \multirow{4}{*}{ Enteromorpha flexuosa } & 24 & $95.7 \mathrm{~b}$ & $66.7 \mathrm{i}-\mathrm{k}$ & $60 \mathrm{k}-\mathrm{m}$ & $0.0 \mathrm{y}$ & $0.0 \mathrm{y}$ & $0.0 \mathrm{y}$ & \multirow{4}{*}{$59.5 \mathrm{~d}$} \\
\hline & 48 & $100 \mathrm{a}$ & $100 \mathrm{a}$ & $81 \mathrm{f}$ & 41 op & $37.7 \mathrm{pq}$ & $31 q-s$ & \\
\hline & 72 & $100 \mathrm{a}$ & $100 \mathrm{a}$ & 83.3 ef & $67.7 \mathrm{ij}$ & $59 i$ & $47.7 n$ & \\
\hline & 24 & 14.3 uv & $3.3 w-y$ & $2 x$ & $0.0 \mathrm{y}$ & 0.0 y & $0.0 \mathrm{y}$ & \\
\hline \multirow[t]{3}{*}{ Laurencia nidifica } & 48 & $72.3 \mathrm{hi}$ & $52.3 \mathrm{~m}$ & 40 o-q & $35.7 \mathrm{q}$ & $27.7 \mathrm{r}-\mathrm{t}$ & $29 r$ & \multirow[t]{3}{*}{$31.5 \mathrm{~g}$} \\
\hline & 72 & $81 \mathrm{f}$ & $64.3 \mathrm{jk}$ & $50 \mathrm{mn}$ & $37.7 \mathrm{pq}$ & $29 r$ & $29 r$ & \\
\hline & 24 & $4.3 w x$ & $2 x$ & $1 \mathrm{xy}$ & $0.0 \mathrm{y}$ & $0.0 \mathrm{y}$ & $0.0 \mathrm{y}$ & \\
\hline \multirow[t]{3}{*}{ Sargassum muticum } & 48 & $61 \mathrm{kl}$ & 44.3 o & 41 op & $35.7 \mathrm{q}$ & $31 q-s$ & 26 st & \multirow[t]{3}{*}{$29.3 \mathrm{~h}$} \\
\hline & 72 & $72.3 \mathrm{hi}$ & $53.31-n$ & $50 \mathrm{mn}$ & 40 o-q & $37.7 \mathrm{pq}$ & $27.7 \mathrm{r}-\mathrm{t}$ & \\
\hline & 24 & $9 \mathrm{vw}$ & $6.7 v-x$ & 5.7 w & $1 x y$ & $0.0 \mathrm{y}$ & $0.0 \mathrm{y}$ & \\
\hline \multirow[t]{3}{*}{ Ulva lactuca } & 48 & $69 \mathrm{i}$ & $61 \mathrm{kl}$ & $54.3 \mathrm{Im}$ & 45.7 no & $35.7 \mathrm{q}$ & $27.7 \mathrm{r}-\mathrm{t}$ & \multirow[t]{3}{*}{$35.7 \mathrm{f}$} \\
\hline & 72 & $72.3 \mathrm{hi}$ & $62.3 \mathrm{k}$ & 60 k-m & $53.3 \mathrm{I}-\mathrm{n}$ & 45.7 no & $33.3 \mathrm{qr}$ & \\
\hline & 24 & 0.0 y & 0.0 y & 0.0 y & 0.0 y & 0.0 y & $0.0 \mathrm{y}$ & \\
\hline \multirow[t]{2}{*}{ Scenedesmus obliquus } & 48 & $4.3 w x$ & $3.3 w-y$ & $0.0 \mathrm{y}$ & $0.0 \mathrm{y}$ & $0.0 \mathrm{y}$ & $0.0 \mathrm{y}$ & \multirow[t]{2}{*}{$1.7 \mathrm{i}$} \\
\hline & 72 & $12 u-w$ & $10 v$ & $0.0 \mathrm{y}$ & $0.0 \mathrm{y}$ & $0.0 \mathrm{y}$ & $0.0 \mathrm{y}$ & \\
\hline \multirow{3}{*}{ Cyanosarcina fontana } & 24 & $69 \mathrm{i}$ & 40 o-q & $36.7 p-r$ & $31 q-s$ & $22.3 \mathrm{t}$ & $20 \mathrm{t}-\mathrm{v}$ & \multirow{3}{*}{$42.4 \mathrm{e}$} \\
\hline & 48 & $76.7 \mathrm{gh}$ & $53.31-n$ & $46.7 n-p$ & $39 p$ & $26.7 \mathrm{~s}$ & $21 \mathrm{tu}$ & \\
\hline & 72 & $80 \mathrm{fg}$ & 60 k-m & $54.3 \mathrm{Im}$ & $39 p$ & $26.7 \mathrm{~s}$ & $21 \mathrm{tu}$ & \\
\hline \multirow{2}{*}{ Dilsea carnosa } & 24 & $95.7 \mathrm{~b}$ & $86.7 \mathrm{~d}-\mathrm{f}$ & 84.3 ef & $79 \mathrm{~g}$ & $66.7 \mathrm{i}-\mathrm{k}$ & $62.3 \mathrm{k}$ & \multirow{3}{*}{$82.9 \mathrm{~b}$} \\
\hline & 48 & $100 \mathrm{a}$ & $93.3 \mathrm{bc}$ & $87.7 \mathrm{de}$ & $81 \mathrm{f}$ & $74.3 \mathrm{~h}$ & $65.7 \mathrm{j}$ & \\
\hline \multirow[b]{3}{*}{ Codium fragile } & 72 & $100 \mathrm{a}$ & 100 a & $93.3 \mathrm{bc}$ & $82.3 \mathrm{e}-\mathrm{g}$ & $74.3 \mathrm{~h}$ & $65.7 \mathrm{j}$ & \\
\hline & 24 & $95.7 \mathrm{~b}$ & $93.3 \mathrm{bc}$ & $82.3 \mathrm{e}-\mathrm{g}$ & $75.7 \mathrm{~g}-\mathrm{i}$ & $75.7 \mathrm{~g}-\mathrm{i}$ & $69 i^{\circ}$ & \multirow{4}{*}{$86.7 \mathrm{a}$} \\
\hline & 48 & $100 \mathrm{a}$ & 95.7 b & $87.7 \mathrm{de}$ & 84.3 ef & 83.3 ef & $79 \mathrm{~g}$ & \\
\hline \multirow{4}{*}{ Cystoseira myrica } & 72 & $100 \mathrm{a}$ & $100 \mathrm{a}$ & $91 \mathrm{~cd}$ & 85.7 e & 83.3 ef & $81 \mathrm{f}$ & \\
\hline & 24 & $89 \mathrm{~d}$ & $80 \mathrm{fg}$ & $74.3 \mathrm{~h}$ & $62.3 \mathrm{k}$ & $47.7 \mathrm{n}$ & 41 op & \\
\hline & 48 & $92.3 \mathrm{~b}-\mathrm{d}$ & $87.7 \mathrm{de}$ & $80 \mathrm{fg}$ & $66.7 \mathrm{i}-\mathrm{k}$ & 60 k-m & 591 & \multirow[t]{2}{*}{$73.3 \mathrm{c}$} \\
\hline & 72 & $96.7 \mathrm{ab}$ & $93.3 \mathrm{bc}$ & 84.3 ef & $74.3 \mathrm{~h}$ & 67.7 ij & $62.3 \mathrm{k}$ & \\
\hline \multirow{3}{*}{$\mathrm{N}$ alone $(\mathrm{Ck})^{\mathrm{c}}$} & 24 & \multicolumn{6}{|c|}{$0.0 \mathrm{y}$} & \multirow{4}{*}{$0.0 \mathrm{j}$} \\
\hline & 48 & \multirow{2}{*}{\multicolumn{6}{|c|}{$\begin{array}{l}0.0 \mathrm{y} \\
0.0 \mathrm{y}\end{array}$}} & \\
\hline & 72 & & & & & & & \\
\hline Conc. Mean & & $62.0 \mathrm{a}$ & $53.7 \mathrm{~b}$ & $47.7 \mathrm{c}$ & $38.6 \mathrm{~d}$ & $33.7 \mathrm{e}$ & $27.1 \mathrm{f}$ & \\
\hline
\end{tabular}


Among interaction between the three factors tested, $C$. fragile and $D$. carnosa treatments at the concentrations of 80 and $60 \%$ gave $100 \%$ mortality after $72 \mathrm{~h}$ from exposure, whereas, C. myrica with the same concentrations gave 96.7 and $93.3 \%$, respectively after the same exposure period. Moreover, these algal species with the lowest concentration (5\%) killed 81, 65.7 and $62.3 \%$ for C. fragile, D. carnosa and C. myrica, respectively after the same exposure time. The $L_{50}$ value was $40 \%$ for L. nidifica and S. muticum extracts after $72 \mathrm{~h}$ of exposure.

Characteristic shapes of dead nematodes were shown in (Fig. 1). It is clear that they had either one of four very distinct shapes i.e. straight (I shape), bent (banana-shape), sigmoid ( $\sum$-shape) and curved (c-shape) after $72 \mathrm{~h}$ exposure to the highest concentration of the algal extract. The dead nematodes from $U$. lactuca or $S$. obliquus or L. nidifica or $C$. fontana groups mostly was straight (I shape) with only very few showing a bent (banana) shape. The appearance of nematodes killed by C. fragile, D. carnosa, C. myrica, E. flexuosa and S. muticum was sigmoid ( $\sum-$ shape) with some curved shape.
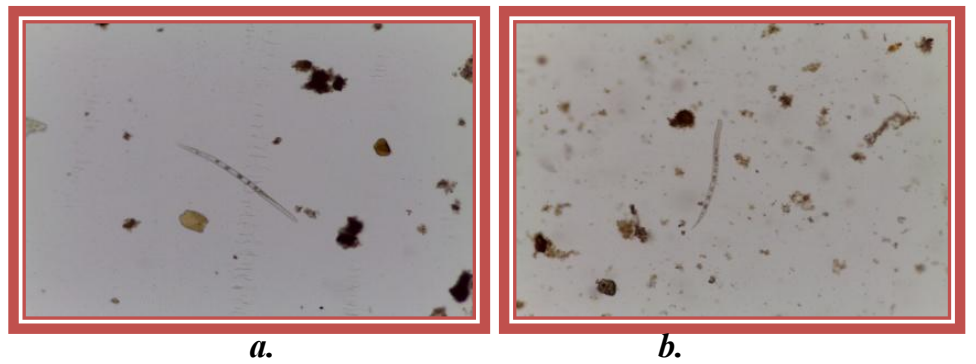

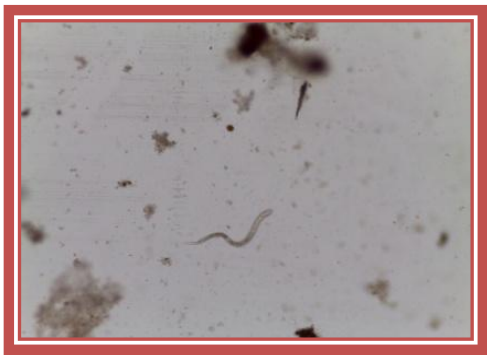

c.

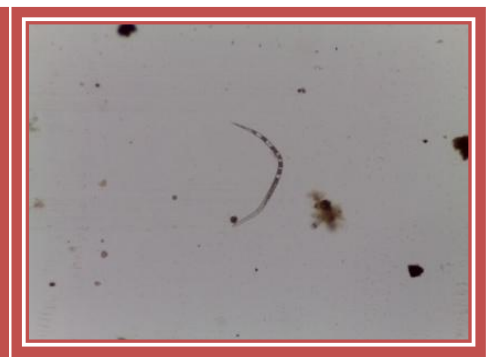

d.

Figure (1): Characteristic shapes of dead nematodes: a. straight (I shape), b. bent (banana-shape), c. sigmoid ( $\Sigma$-shape), and d. curved (c-shape) after exposure to the highest concentration of the algal extract.

\section{Discussion}

Using bioagents against root-knot nematodes is a desire trend for existing a nematode management program. Of these materials, there are algae. Utilization of such natural compounds has earned much more benefits in excreting nematode (Rizvi and Shameel, 2006; Manilal et al., 2011; Nour El-Deen et al., 2013; Kumar, 2014; Khan et al., 2015). 
Apparently, results from the present in vitro experiment indicated that tested algal species, concentrations and exposure periods directly affect hatchability of nematode eggs as well as mortality of newly hatched second stage juveniles. It is evident that the aqueous extracts of $E$. flexuosa, $D$. carnosa and $C$. fragile algae reduced the egg hatching of $M$. incognita, whereas, $C$. fontana and S. obliquus increased the number of hatched eggs. However, S. muticum, U. lactuca, C. myrica and $L$. nidifica extracts showed moderate nematicidal activity on egg hatching. These findings disagreed with Khan et al. (2015) in respect to Saragassum, Ulva and Laurencia algae which gave the lowest values for egg hatching and larval mortality percentages, whereas, agreed with him in respect to Codium. In the present work, it was clear that egg hatching decreased with increase in extract concentrations of E. flexuosa, D. carnosa, C. fragile, C. myrica, S. muticum and $L$. nidifica; however, increasing the concentration of $C$. fontana, S. obliquus and $U$. lactuca extracts increased egg hatching percentages. These results indicated that the first algal group may contain secondary metabolites inhibit egg hatching of $M$. incognita, whereas, the second group seems to be has stimulating constituents for hatching the eggs. Our results supported the findings of Manilal et al. (2012) who recorded that the bioactivity exhibited by Lobophora variegate might be due to the synergistic activity of seven fatty acids.

Regarding larval mortality, results of the present investigation showed that $E$. flexuosa algae gave a considerable percentage of larval mortality although it was the best treatment in suppressing egg hatching. All concentrations of $C$. fragile, $D$. carnosa and $C$. myrica algae were highly toxic to $\mathrm{J}_{2} \mathrm{~s}$ of $M$. incognita after $72 \mathrm{~h}$ exposure; however, less than $50 \%$ of larvae were killed by low concentration of $E$. flexuosa. S. obliquus extract seems to be non toxic to nematodes, since most of concentrations tested not able to kill larvae. These results are in accordance with Massa (2010) who showed that the seaweed extract has no toxic effect on the $J_{2}$ upon exposure to the product for longer period and this confirms an earlier report by Wu et al. (1998) in this respect. Nematode killing mechanism may be attributed to a direct effect of cyanobacterial neurotoxins. However, Wu et al., (1997) recorded that betaines of the brown alga Ascophyllum nodosum caused a reduction of $M$. javanica and $M$. incognita infection on tomato.

The observed characteristic differences in shape of the nematodes killed by aqueous algal extracts was an interesting finding that might be useful as an indication to analyze the major mode of toxic action of these natural biocide. The present finding showed that the nematodes killed by $C$. fragile, D. carnosa, $C$. myrica, E. flexuosa and S. muticum was sigmoid ( $\Sigma$-shape) with some curved shape, which was similar to those killed by the acetylcholine esterase inhibitors; whereas, the appearances of the nematodes killed by other algal species mostly followed straight or bent shapes, similar to those killed by the pyrethroid. This finding is in line with the report of Wiratno et al. (2009) who mentioned that the 
shapes of the dead nematodes differed in a characteristic way, and groups of pesticides and plant extracts could clearly be distinguished based on this phenomenon. Based on the shapes of the dead nematodes, it is suggested that most of the algal extracts tested had a pyrethroid-like effect on the central nervous system of the nematodes.

Obviously, results of this investigation indicated that the nine algal extracts tested could be divided into 4 main groups based on their toxicity i.e. highly toxic (>70\% mortality), consisting of $C$. fragile and $D$. carnosa; moderately toxic $(41-70 \%$ mortality), consisting of C. myrica, E. flexuosa and C. fontana; slightly toxic (10-40 $\%$ mortality) consisting of $U$. lactuca, L. nidifica and S. muticum and not toxic $(<10 \%$ mortality) consisting of $S$. obliquus extract. Finally, this initial study was conducted to isolate and identify nine algal species from Jeddah and Taif those offer nematicidal proprieties against root-knot nematode, which have not been the subject of previous studies in Saudi Arabia. So our results offer reliable base for promising nematode control method, further investigations are necessary, especially under greenhouse and field conditions.

\section{References}

Bliss, C.I. (1937). Table A. 10. Transformation of bionomial percentages (Arcsin). This table appeared in Plant Protection (Leningrad), 12 (67): 448-449.

Duncan, D.B. (1955). Multiple rang and multiple, F-test. Biometrics, 11: 1-42.

Gomez, K.A. and A.A. Gomez (1984). Statistical Procedures for Agricultural Research. $2^{\text {nd }}$ Ed .,John Wiley\&Sons. Inc. New York.

Guiry, M.D. and G.M. Guiry (2013). AlgaeBase. Worldwide electronic publication, National University of Ireland, Galway. http://www.algaebase.org; last accessed 15 August 2013.

Hussey, R.S. and K.R. Barker. (1973). A comparison of methods of collecting inocula of Meloidogyne spp. including a new technique. Plant Disease Reporter, 57: 1925-1928.

Ibrahim, I.K.A.; M.A.M. EL-Saedy and Asmaa A. Mokbel (2007). Control of the root-knot nematode Meloidogyne incognita on sunflower plants with certain organic plant materials and biocontrol agents. Egypt. J. Phytopathol., 35 (1): $13-24$.

Issa, A.A.; F.A. Shaieb and R.M. Al-Sefat (2015). Role of cloacal algae in the treatment of wastewater and their biotechnological applications. Bioscience and Bioengineering, 3: 48-56.

Khan, S.A.; M. Abid; F. Hussain (2015). Nematicidal activity of seaweeds against Meloidogyne javanica. Pakistan Journal of Nematology 33(2): 195-203. 
Kumar, M. (2014). Cyanobacteria: natural occurring untapped valuable resource. Indo American Journal of Pharmaceutical Research, 4 (2): 1234-1237.

Luc, M.; R.A. Sikora and J. Bridge (2005). Plant parasitic nematodes in subtropical and tropical agriculture. CAB International, Wallingford, UK. 871 pp.

Manilal, A.; S. Sujith; B. Sabarathnam; J. Selvin; G.S. Kiran; C. Shakir and A.P. Lipton (2011). Biological activity of the red alga Laurencia brandenii. Acta Botanica Croatica, 70 (1): 81-90.

Manilal, A.; S. Joseph; T. Nooruddin; S. Sugathan; P. Mvn; I. Akbar and S.K. Radhakrishnan (2012). Biopotentials of marine alga, Lobophora variegata collected from the South Indian Littoral. Thalassas, 28 (1): 47-54.

Massa, N.B. (2010). The use of seaweed-based products from Ecklonia maxima and Ascophylum nodosum as control agents for Meloidogyne chitwoodi and M. hapla on tomato plants. MSc thesis, Ghent University, 29 pp.

Nour El-Deen, A.H.; Omaima M. Abdel-Kafie and Naira M. El-Ghareb (2013). Evaluation of seaweed extract and various plant products against Meloidogyne incognita on basil. Georgikon for Agriculture, 16 (1): 29-34.

Paracer, S.M.; A.C. Tarjan and L.M. Hodgson (1987). Effective use of marine algalproducts in the management of plant parasitic nematodes. J. Nematol., 19: $194-200$.

Rizvi, M.A. and M. Shameel (2006). In vitro nematicidal activities of seaweed extracts from Karachi coast. Pak. J. Bot., 38 (4): 1245-1248.

Rubal, M.; P. Veiga; R. Vieira and I. Sousa-Pinto (2011). Seasonal patterns of tidepool macroalgal assemblages in the North of Portugal. Consistence between species and functional group approaches. J. Sea Res., 66: 187194.

Sasser, J.N. and D.W. Freckman (1987). A world perspective on nematology: The role of the society. P: 7-14 in J. A. Veech and D.W. Dickson, eds. Vistas on Nematology. Hyattsville, M. D: Society of Nematologists.

Sasser, J.N.; J.D. Eisenback; C.C. Carter and A.C. Triantaphyllou (1983). The international Meloidogyne project, its goals and accomplishments. Annual Review of Phytopathology, 21: 271-288.

Shimizu, Y. (2003). Microalgal metabolites. Current Opinion in Microbiology, 6: 236-242.

Taylor, A.L. and J.N. Sasser (1978). Biology, identification and control of root-knot nematodes (Meloidogyne species). Coop. Publ, Dep. Plant Pathol., North Carolina State Univ., and U.S. Agency Int. Dev., Raleigh, NC.,111 pp. 
Wiratno, A.; D. Taniwiryonoc; H. Van den Bergb; J.A.G. Riksend; I.M.C.M. Rietjensb; S.R. Djiwantia; J.E. Kammengad and A.J. Murkb (2009). Nematicidal activity of plant extracts against the root-knot nematode, Meloidogyne incognita. The Open Natural Products Journal, 2: 77-85.

Wu, Y.; T. Jenkins; G. Blunden; C. Whapham and S.D. Hankins (1997). The role of betains in alkaline extracts of Ascophyllum nodosum in reduction of Meloidogyne javanica and $M$. incognita infestations of tomato plants. Fundamental and Applied Nematology, 20: 99-102.

Wu, Y.; T. Jenkins; G. Blunden; N.V. Mende and S.D. Hankins (1998). Suppression of fecundity of the root-knot nematode, Meloidogyne javanica, in monoxenic cultures of Arabidopsis thaliana treated with an alkaline extract of Ascophyllum nodosum. Journal of Applied Phycology, 1: 91-94.

Zaki, M.J.; Zareen, A.; A. Sattar and M.Q. Khan (2005). Effect of seaweeds on the efficacy of Pasteuria penetrans in the control of root-knot nematode, Meloidogyne javanica in eggplant. International Journal of Phycology and Phycochemistry, 1: 65-72.

Zuckerman, B.M. and J. Esnard (1994). Biological control of plant nematodescurrent status and hypothesis. Japanese Journal of Nematology, 24: 1-13. 


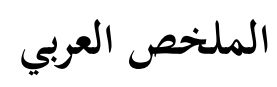

الخصائص الإبادية للمستخلص المائي لبعض الطحالب ضد نيماتودا تعقد الجذور

$$
\begin{aligned}
& \text { (ميلويدوجين انكوجنيتا) في المعمل }
\end{aligned}
$$

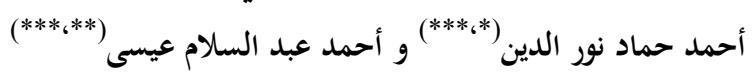

$$
\begin{aligned}
& \text { * وحدة بحوث النيماتولوجي- قسم الحيوان الزراعي- كلية الزراعة- جامعة المنصورة- جمهورية مصر العربية. } \\
& \text { ** قسم النبات- كلية العلوم-جامعة أسيوط- جمهورية مصر العربية. } \\
& \text { *** * *مم الأحياء-كلية العلوم-جامعة الطائف- المملكة العربية السعودية. }
\end{aligned}
$$

تم دراسة تأثير المستخلص المائي لتسعة أنواع من الطحالب بتركيزات مختلفة على فقس

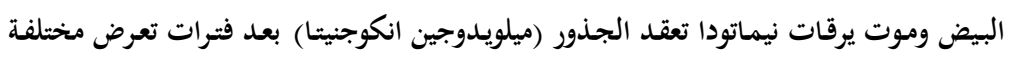

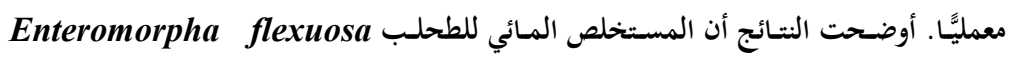

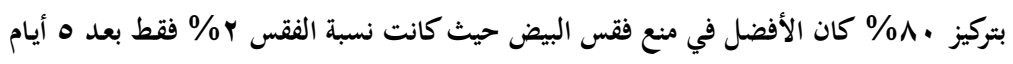

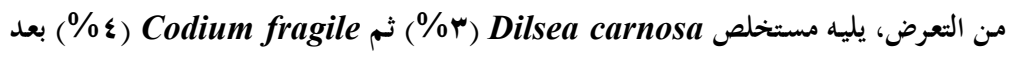

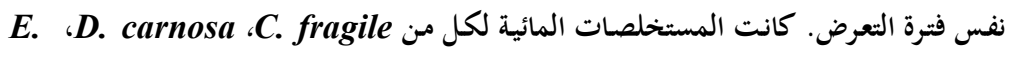
Cystoseira myrica flexuosa

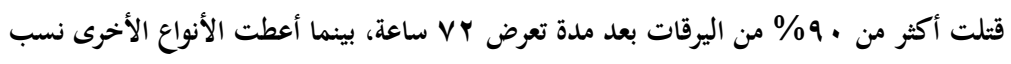

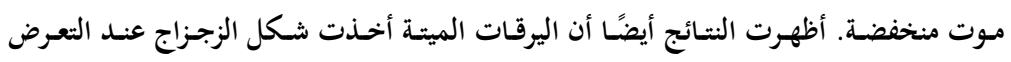
لمستخلصـات كسل مـ E. flexuosa ،C. Myrica (D. carnosa ،C. fragile

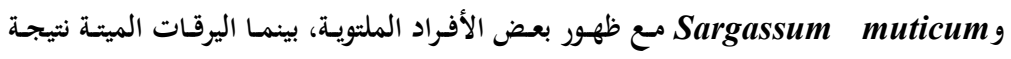

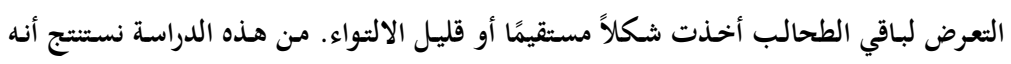

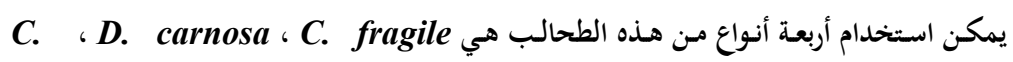
E. flexuosag myrica 